\title{
Geographical Information System Approach to Delineate the Watershed's Morphometric Parameters for Sustainable Hydrological Modeling of Barind Region, Bangladesh
}

\author{
Md. Ashikur Rahman ${ }^{1}$, M. H. Sazzad ${ }^{2}$, and R. S. Rupom ${ }^{3}$ \\ ${ }^{1}$ Institute of Bay of Bengal \& Bangladesh Studies, BSMR Maritime University Bangladesh, Dhaka-1216, Bangladesh \\ 2 Department of Urban \& Regional Planning, Khulna University of Engineering \& Technology, Khulna-9203, Bangladesh \\ ${ }^{3}$ Department of Urban \& Regional Planning, Rajshahi University of Engineering \& Technology, Rajshahi-6204, Bangladesh \\ emails: ${ }^{* 1}$ ro.ibbbs@bsmrmu.edu.bd; ${ }^{2}$ planner.sazzad@gmail.com; and ${ }^{3}$ rubayatshahriarrupom18@gmail.com;
}

\section{ARTICLE INFO}

\section{Article History:}

Received: 03rd September 2020

Revised: 02 ${ }^{\text {nd }}$ March 2021

Accepted: 17th March 2021

Published: 27th June 2021

\section{Keywords:}

Geographical Information System GIS

Remote Sensing

Watershed

Morphometric Parameter

Sustainable Hydrological Mode

\begin{abstract}
A B S T RA C T
Water is an important resource of the earth's surface and it is integral for all on this planet. The availability or the scarcity of water depends on the watershed characterizes that consider the basic, linear, and shape parameters of any waterbody. The objective of the study was to delineate 14 morphometric parameters in the Barind region (Dinajpur district, Bangladesh) for sustainable hydrological modeling. An ASTER-DEM of 30-meter resolution data, geographical information system (GIS), and Remote sensing technique were used for extracting drainage components of interest region. The whole study region was covered by the flow of the Purnovoba river, Jamuna river, Atrai river (part-1 and part-2). Research results found that the Purnovoba river had a high bifurcation ratio (0.9982) that defined hydrologically more disturbed than the other three watershed areas and it had a high stream frequency (0.8332) that denoted rocky having low infiltration capacity. Jamuna river had a low drainage density (0.7322) that defined more vegetation having higher permeability. Besides, the Jamuna river had the lowest no. of stream order that was insignificant in the steady runoff process and less prone to cause a flash flood. The research predicted that the availability of groundwater might decrease to Jamuna river in the future as it had the lowest basin area (217.42 sqr. km ) and perimeter $(114.90 \mathrm{~km})$ and the basin surface slope would become gentle to Atrai river part-1 for the lowest length of overland flow (0.6072). Purnovoba river experienced the lowest form factor (0.2351) which indicated the most possibility for erosion. The elongated ratio of all basins was greater than 0.5 which considered all the shapes were more elongated. These findings will help for further modeling of an integrated watershed for sustainable hydrological models in the Barind region.
\end{abstract}

\section{INTRODUCTION}

Land and water resources both are vital elements of the earth as life depends on them. But these resources are being limited due to rapid population rises and other activities. Watershed management is a crucial part of the conservation and utilization of the natural resources in the water bodies (B.-W. Liu et al., 2020; Rong et al., 2019). Effective watershed management can play an important role in managing the damage runoff ( $\mathrm{Fu}$ et al., 2019), reducing the impact of sediment output and river erosion (Du et al., 2016), increasing groundwater storage
(Ghorbani Nejad et al., 2017), and utilizing land and water resources (Ervinia et al., 2019; Wada et al., 2020). A watershed is a region that sustains all kinds of runoff of the stream, lake, or ocean. Watershed's morphometric modeling is commonly used for sustainable watershed management (Ahn \& Kim, 2019; Alnahit et al., 2020), resource protection (Wada et al., 2020), and sustainable development (Prasannakumar et al., 2013; Sujatha et al., 2014) in any region. Morphometric analysis is an important method for hydrological research that provides the quantitative results of drainage basins (Choudhari et al., 2018). Besides, morphometric analysis of watershed 
includes the preparation of drainage map with the order of drainage streams, catchment area, and perimeter, stream order, and stream length (Alam et al., 2020; Charizopoulos et al., 2019). Three morphometric parameters such as basic parameters (Banerjee et al., 2017; Choudhari et al., 2018; Elsadek et al., 2019; Gajbhiye et al., 2014), linear parameters (Gajbhiye et al., 2014; Patel et al., 2012), and shape parameters (Ahmed et al., 2010; Gajbhiye et al., 2014; Panhalkar et al., 2012; Patel et al., 2012) are used to characterize the watershed. The basic parameters characterize the area, perimeter, basin length, stream order, stream length, maximum and minimum height, and slope. Basin length is considered as a straight-line interval from a basin mouth to the outlet point (Senter et al., 2017; Soni, 2017). The linear parameters are analyzed for the stream order, stream length, mean stream length, and bifurcation ratio (Harsha et al., 2020). The mean stream length is related to the drainage network and corresponds with its surface (Dragičević et al., 2018; Pondari et al., 2020). The shape parameters include the form factor, shape factor, elongation ratio, compactness coefficient, and circulatory ratio (Al-Assadi, 2020; Saha et al., 2020). Though linear parameters have a substantial effect on erodibility, but the shape parameters have negative relationship on erodibility (Ratnam et al., 2005).

Conducting watershed analysis and hydrological research for large drainage basins catchment areas through topographical maps or field observation are quite impossible but in small watersheds, it can be measured streamflow and water quality (Choudhari et al., 2018; Harmel et al., 2006). Recently, researchers used geospatial techniques like Geographical Information System (GIS) and Remote Sensing (RS) for sustainable watershed analysis and modeling. GIS and RS techniques have high efficiency and effectiveness for extraction of drainage components (Gong \& Xie, 2009; Metz et al., 2011), watershed development, and management (Ameri et al., 2018; Chatterjee et al., 2014; Okumura \& Araujo, 2014). Nowadays GIS techniques are inexpensive, reliable, and fast way to calculate morphometric analysis (Balasubramanian et al., 2017; Sreedevi et al., 2009) and used for drainage pattern, topography, and subsurface material studies (Balasubramanian et al., 2017; Chandniha \& Kansal, 2017; Javed et al., 2011; Withanage et al., 2014). RS data offer accurate, timely, and real-time information about specific aspects such as watershed size and form, soil distribution, drainage characteristics, etc (Suresh et al., 2004).

Elsadek. W. M. et al., 2019 have analyzed the morphometric characteristics to estimate the flood risk hazards of sub-watersheds using morphometric analysis in Qena watersheds. In their research, the shuttle radar topography mission (STRM) data are used to analyze the topography, modeling of surface processes, and flood risk zone. The calculation of hydrological parameters, extraction of topography map, drainage network, and the direction of the flow of floods are analyzed by GIS techniques (Elsadek et al., 2019). Choudhari, P. P. et al., 2018 have analyzed the morphometric parameters and prioritization of sub-watersheds for groundwater potential and conservation structures for a watershed of the Mula river basin in the Puna district of Maharashtra, India. The prioritization of five watersheds of the Mula river is graded by computing morphological parameters where the lowest ranking is represented the top priority of soil erosion and less measure of conservation. In their research, the STRM data and GIS technique are used for estimating morphometric parameters of the Mula river basin (Choudhari et al., 2018).

The present research contributes to delineate the 14 morphometric parameters in the Barind region where there is limited such research work in Bangladesh. The research findings will help for further modeling of an integrated watershed for sustainable hydrological models. Besides, it will help for solving hydrology-related problems such as irrigation, harvesting of surface water, cause of river erosion, surface stormwater runoff process, and water resource management in the Barind region.

\section{MATERIALS AND METHODS A. Study Area Profile}

Watershed basin of Dinajpur region is located in between $25^{\circ} 10^{\prime}$ and $26^{\circ} 04^{\prime}$ North latitudes and between $88^{\circ} 23^{\prime}$ and $89^{0} 18^{\prime}$ East longitudes at the Northern part of Bangladesh (Figure 1). It is bounded by Thakurgaon and Panchagram districts on the North, Gaibandha and Joypurhat districts on the South, Nilphamari and Rangpur districts on the East and West Bengal state of India on the West. Geographically it is situated in the Barind region of Bangladesh. The Barind region is influenced by lower rainfall and higher temperature as compared to other regions of Bangladesh (Rashid et al., 2013). Jamuna river, Purnovoba river, and Atrai river are major rivers that pass through the area of interest (AOI). The Dinajpur district experiences a hot, wet, and humid tropical climate. In Bangladesh, the Northern part is the steepest slope than the Southern region (Figure 2). In the AOI the water flow usually happens from the Northern to the Southern direction and it is occurred based on the slope of the land (Figure 3).

\section{B. Data Description}

Digital elevation model (DEM) generated from advanced spaceborne thermal emission and reflection radiometer (ASTER) data were used for this research (K. Liu et al., 2020; Mokarram \& Hojati, 2017; Poongodi \& Venkateswaran, 2018) and they were collected from open topography website (https://opentopography.org/) (Figure 4). The numbers of Columns and rows of the raster data were 1107 and 1000 respectively. Spatial extents of the DEM were 26.05930 degree at the top, 25.22597 degree at the bottom, 88.38231 degree at the left, and 89.30481 degree at right. The pre-processed DEM image was used for extraction and quantification of watershed morphometric parameters. Districts and Upazilla boundary data were collected from the Survey of Bangladesh (SoB). Universal Transverse Mercator (UTM) projection system was used as spatial parameter and World Geodetic System (WGS) 1984 was used as a datum for the data preparation and mappng. 


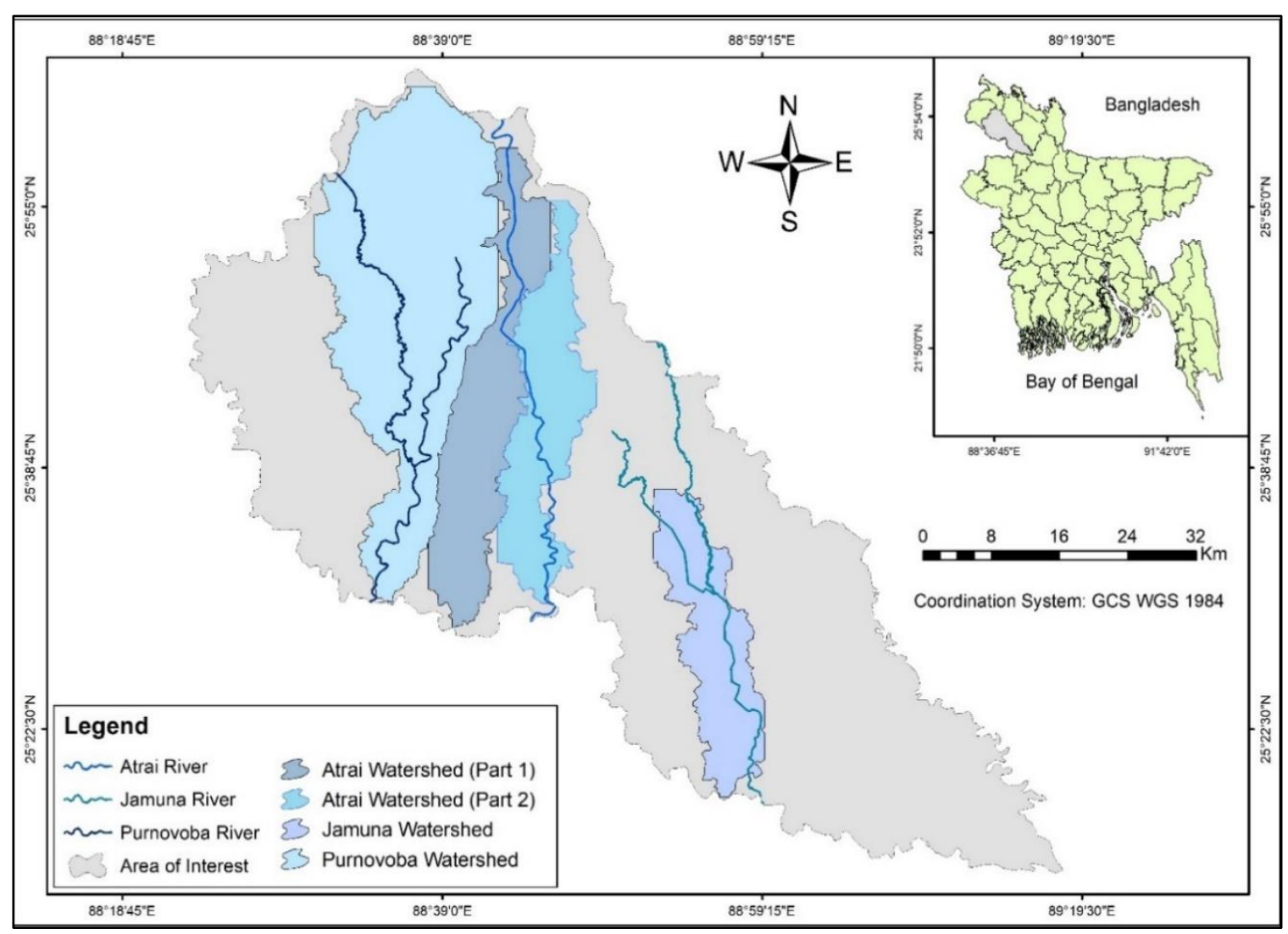

Figure 1: Study area map including major river and watershed in Dinajpur district, Bangladesh

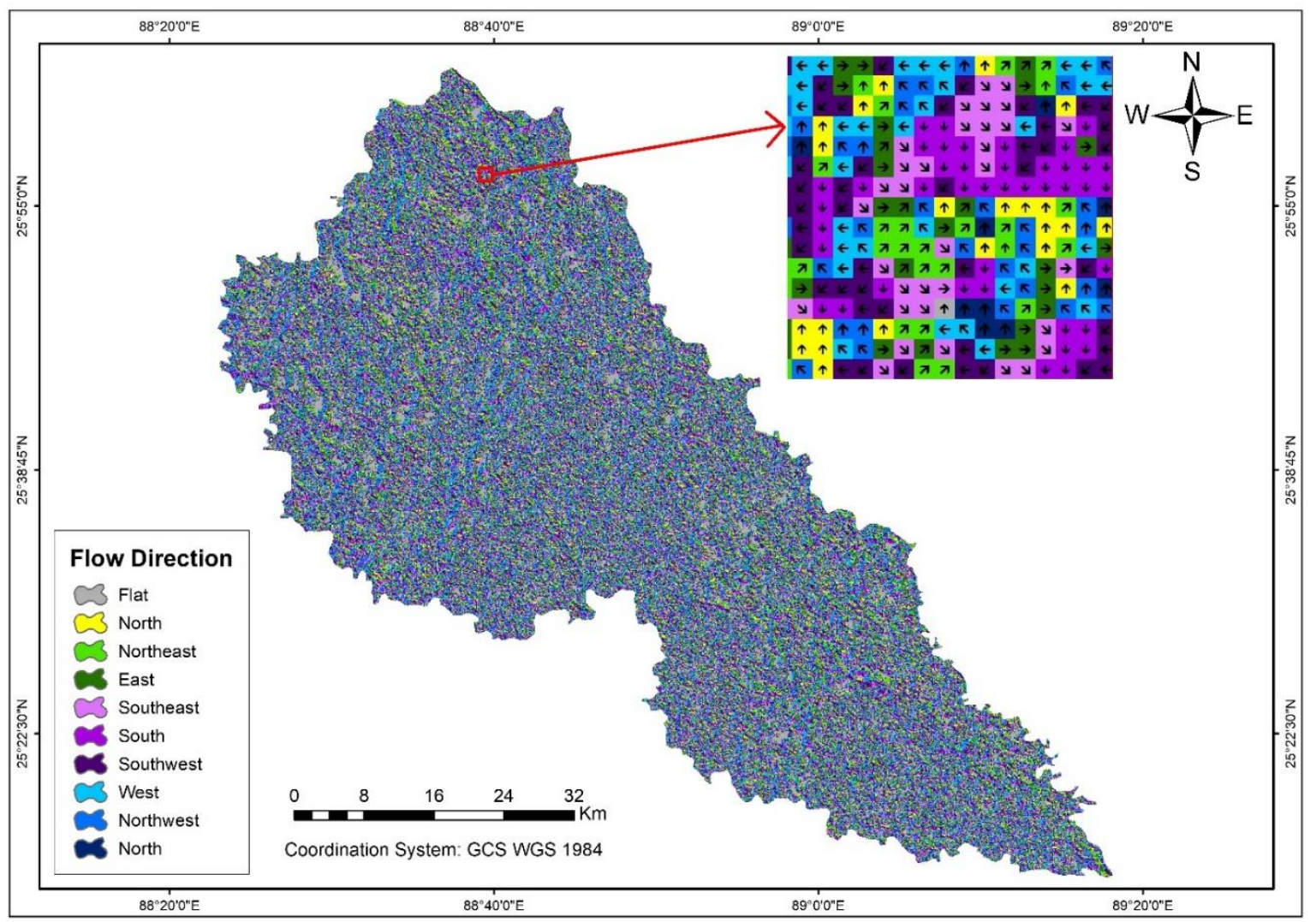

Figure 2: Flow direction of water in the AOI 


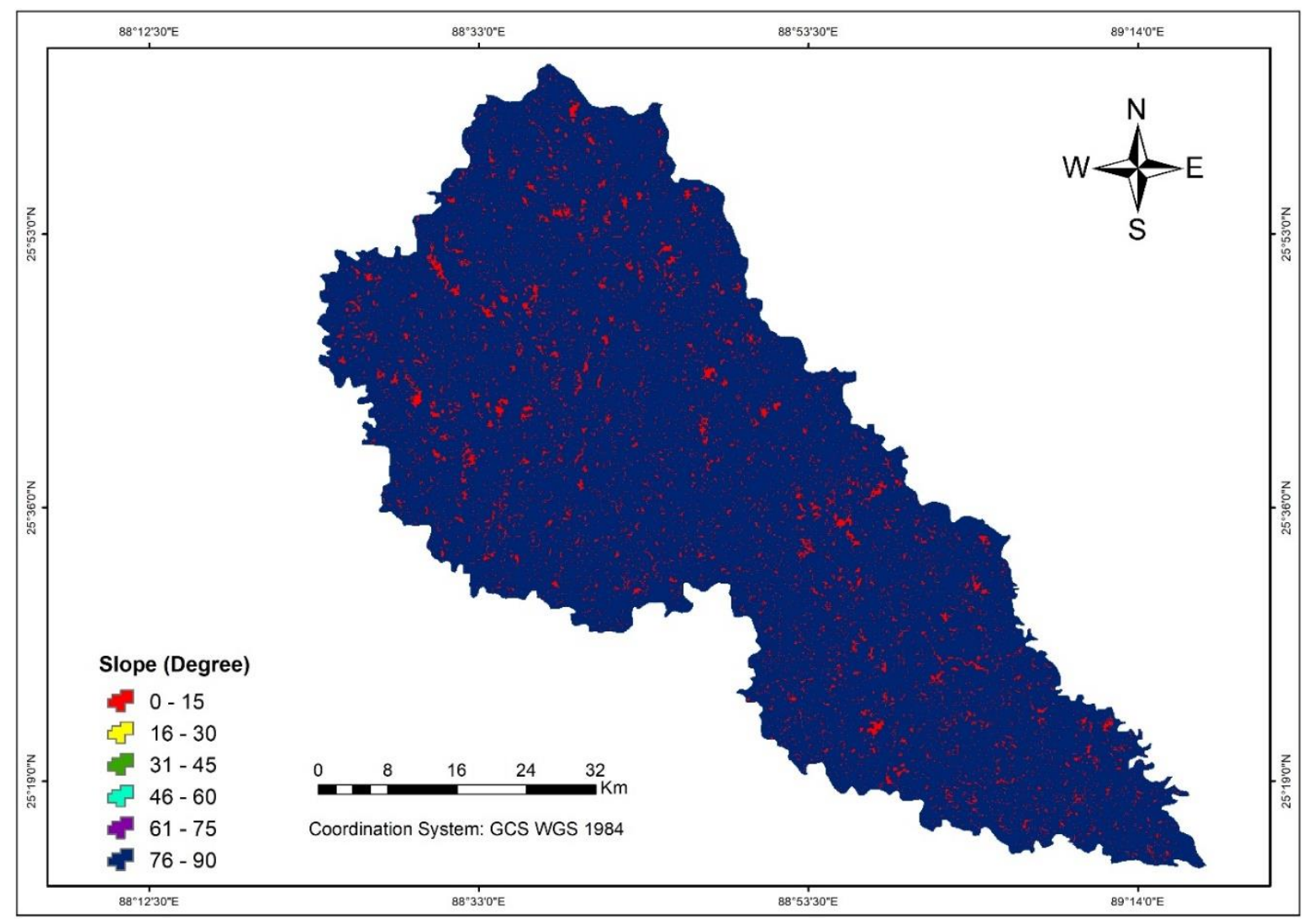

Figure 3: Slope aspect map of Study area

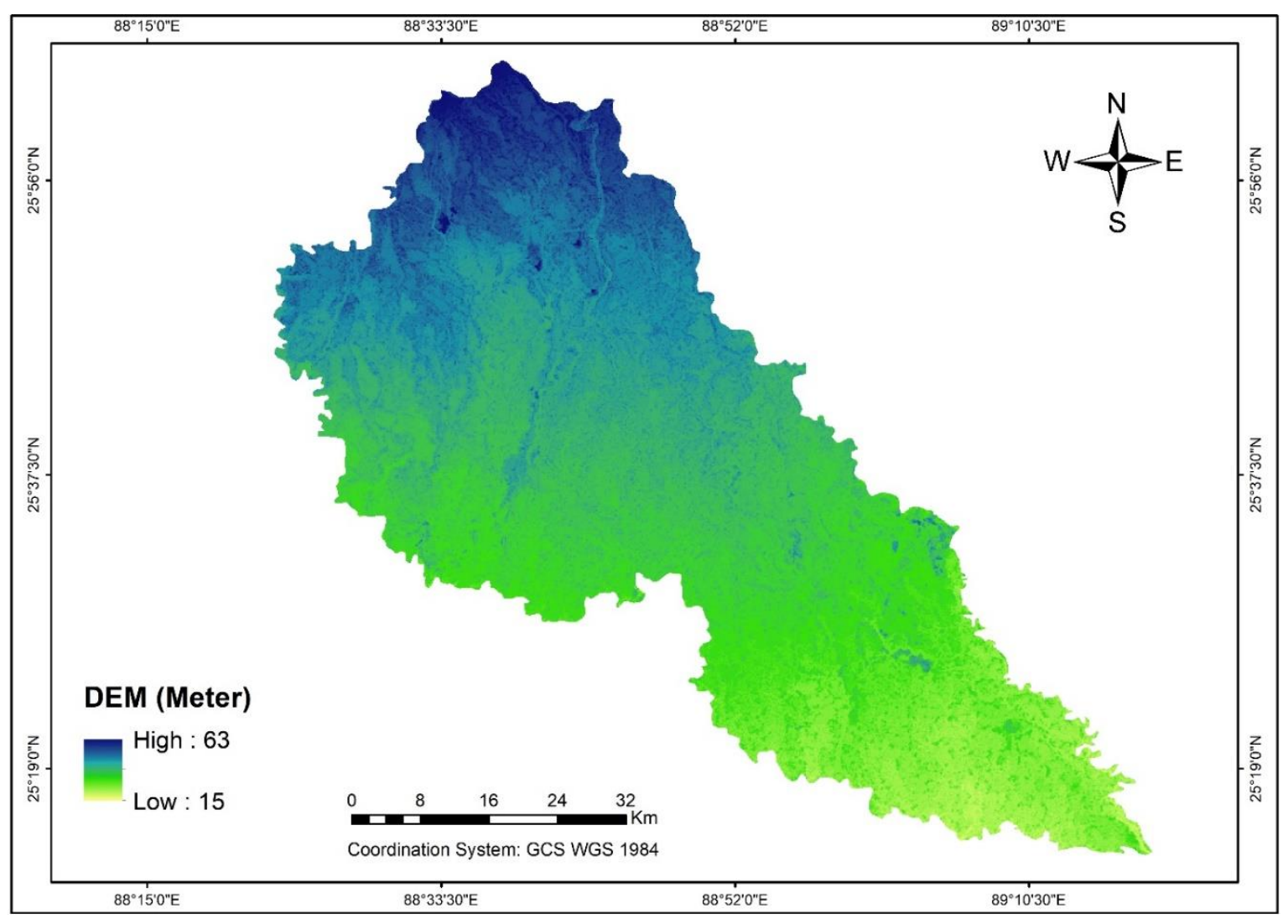

Figure 4: DEM map of Study area 


\section{Morphometric Parameter Analysis Technique and Computation}

Watershed basin created stream orders like $1^{\text {st }}, 2^{\text {nd }}, 3^{\text {rd }}, 4^{\text {th }}$ and $5^{\text {th }}$ order stream depending on the flow characterizes. All the streams in a watershed area were delineated from DEM image using ArcGIS software v 10.7. Firstly, the collected DEM image was reconditioned by a commercial DEM developer, and based on AOI reconditioned DEM was extracted. Secondly, the Flow direction of the analyzed region was computed. Thirdly, the flow accumulation of DEM was computed. Fourthly, the stream network covering the AOI was defined and it was found in a grid format. Fifthly, these grid format data were taken to convert vector data format. Sixthly, stream order was extracted based on theory. Finally, some extreme outlet points were selected of the concerned river, and based on counting outlet points the watershed basins were delineated (Ameri et al., 2018; Amiri et al., 2019; Tykocki et al., 2018).

The watershed of AOI was divided into four sub-watershed basins called Purnovoba river, Jamuna river, Atrai river part-1, and Atrai river part-2 (Figure 1). Five basic parameters, five linear parameters, and four shape parameters were analyzed in the present study. All these parameters were computed using some formulas showing in Table 1 .

Table 1

The list of formulas for computation morphometric parameters in the research

\begin{tabular}{|c|c|c|c|}
\hline No. & Parameter & Formulas & Reference \\
\hline \multicolumn{4}{|c|}{ Basic parameter } \\
\hline 1 & Area $(A)\left(k m^{2}\right)$ & ArcGIS computation & \\
\hline 2 & $\begin{array}{l}\text { The Perimeter of the basin } \\
(\mathrm{P})(\mathrm{km})\end{array}$ & ArcGIS computation & \\
\hline 3 & Stream order $(\mathrm{u})$ & Hierarchical rank (ArcGIS computation) & (Strahler, 1964) \\
\hline 4 & Stream Length (Lu) (km) & ArcGIS computation & \\
\hline 5 & Basin Length (Lb) (km) & $\begin{array}{l}L_{b}=1.321 \times A^{0.568} \\
\text { Where } \mathrm{A}=\text { Basin area }\left(\mathrm{km}^{2}\right)\end{array}$ & $\begin{array}{l}\text { (Ratnam et al., } \\
\text { 2005) }\end{array}$ \\
\hline \multicolumn{4}{|c|}{ Linear parameter } \\
\hline 6 & Bifurcation ratio $(\mathrm{Rb})$ & $\begin{array}{l}R_{b}=N_{u} / N_{u}+1 \text { - } \\
\text { Where } \mathrm{N}_{\mathrm{u}}+1=\text { Segments no. of the next higher order }\end{array}$ & $\begin{array}{l}\text { (Schumm, } \\
1956)\end{array}$ \\
\hline 7 & $\begin{array}{l}\text { Drainage density (Dd) } \\
\left(\mathrm{km} / \mathrm{km}^{2}\right)\end{array}$ & $\begin{array}{l}D_{d}=L_{u} / A \\
\text { Where, } \mathrm{L}_{\mathrm{u}}=\text { Total stream length of all orders }(\mathrm{km}) \text { and } \\
\mathrm{A}=\text { Area of the watershed }\left(\mathrm{km}^{2}\right)\end{array}$ & (Horton, 1945) \\
\hline 8 & $\begin{array}{l}\text { Stream frequency }(\mathrm{Fu}) \\
\left(\text { no. } / \mathrm{km}^{2}\right)\end{array}$ & $\begin{array}{l}F u=N_{u} / A \\
\text { Where, } \mathrm{N}_{\mathrm{u}}=\text { Total no. of steams of all orders and } \\
\mathrm{A}=\text { Area of the basin }\left(\mathrm{km}^{2}\right)\end{array}$ & (Horton, 1945) \\
\hline 9 & $\begin{array}{l}\text { Texture ratio }(\mathrm{T}) \\
\left(\text { no. } / \mathrm{km}^{2}\right)\end{array}$ & $\begin{array}{l}T=N_{u} / P \\
\text { Where } \mathrm{N}_{\mathrm{u}}=\text { total no. of streams of all orders and } \\
\mathrm{P}=\text { Perimeter }(\mathrm{km})\end{array}$ & (Horton, 1945) \\
\hline 10 & $\begin{array}{l}\text { Length of overland flow, } \\
\text { Lo }(\mathrm{km})\end{array}$ & $\begin{array}{l}L_{o}=1 / 2 D_{d}--(6) \\
\text { Where } \mathrm{D}_{\mathrm{d}}=\text { Drainage density }\end{array}$ & $\begin{array}{l}\text { (Horton, 1945); } \\
\text { (Schumm, } \\
\text { 1956) }\end{array}$ \\
\hline \multicolumn{4}{|c|}{ Shape parameter } \\
\hline 11 & Form factor (Rf) & $\begin{array}{l}R_{f}=A / L_{b}^{2} \\
\text { Where, } \mathrm{A}=\text { Basin area }\left(\mathrm{km}^{2}\right) \text { and } \mathrm{Lb}=\text { Basin length }(\mathrm{km})\end{array}$ & (Horton, 1945) \\
\hline 12 & Shape factor (Bs) & $\begin{array}{l}B_{S}=L_{b}^{2} / A \\
\text { Where } \mathrm{L}_{\mathrm{b}}=\text { Basin length }(\mathrm{km}) \text { and } \mathrm{A}=\text { Area of the basin }\left(\mathrm{km}^{2}\right)\end{array}$ & (Horton, 1945) \\
\hline 13 & Elongation ratio (Re) & $\begin{array}{l}R_{e}=1.128 \sqrt{ }\left(A / L_{b}\right) \\
\text { Where } \mathrm{A}=\text { area of the basin }\left(\mathrm{km}^{2}\right) \text { and } \mathrm{L}_{\mathrm{b}}=\text { Basin length }(\mathrm{km}) .\end{array}$ & $\begin{array}{l}\text { (Schumm, 1956; } \\
\text { Strahler, 1964) }\end{array}$ \\
\hline 14 & $\begin{array}{l}\text { Compactness } \\
\text { (Cc) }\end{array}$ & $\begin{array}{l}\boldsymbol{C} \boldsymbol{c}=\frac{P}{2 \sqrt{\pi} \boldsymbol{A}} \\
\text { Where } \mathrm{P}=\text { Perimeter of the basin }(\mathrm{km}) \text { and } \\
\mathrm{A}=\text { area of the basin }\left(\mathrm{km}^{2}\right)\end{array}$ & (Horton, 1945) \\
\hline
\end{tabular}




\section{RESULTS AND DISCUSSION}

\section{A. Area (A) and Perimeter of the Basin (P)}

Area and perimeter were the basic parameters of a watershed basin and these were described in the way of the extent of the basin over a watershed region. The research focused on the area of four analyzed watersheds that were $699.664 \mathrm{~km}^{2}, 217.424 \mathrm{~km}^{2}, 244.047 \mathrm{~km}^{2}$, and 298.788 $\mathrm{km}^{2}$ for Purnovoba river, Jamuna river, Atrai river part-1, and Atrai river part-2 watershed basin area respectively. The minimum and maximum perimeters were 187199.00 $\mathrm{km}$ for Purnovoba river and $114.907 \mathrm{~km}$ for Jamuna river (Table 2). So, the availability of groundwater might decrease in the Jamuna river watershed region in the future as its basin area and perimeter were low.

\section{B. Stream Order (u)}

Higher stream order denoted the higher discharged rate and greater velocity of a stream while lower-order was described as opposite. The maximum stream order was demarked as $5^{\text {th }}$ order stream and the minimum was demarked as $1^{\text {st }}$ order. Analyzed results showed that there was a total of 1214 no of the stream (Table 2). Increasing the order decreased the number of streams. The $1^{\text {st }}$ order stream contained the highest number of stream orders in the study area. The $5^{\text {th }}$ order stream was found in the Purnovoba river watershed area which was denoted the main river stream (Figure 5d; Fig. 6a). The $1^{\text {st }}$ to $4^{\text {th }}$ order stream was found in both Atrai river part-1 and Atrai river part-2 (Figure 5a, b; Figure 6a). Only $1^{\text {st }}, 2^{\text {nd }}$, and $3^{\text {rd }}$ order streams were found in the Jamuna river watershed (Figure 5c; Figure 6a).

\section{Stream Length $(\mathrm{Lu})$}

The stream length of a watershed basin represented the travel distance and time of a stream. The total length of all streams was $1117.77 \mathrm{~km}$ in the study area (Table 2). The $1^{\text {st }}$ order stream contained the highest length and the $5^{\text {th }}$ order contained the lowest (Figure 6b). Among them, the Purnovoba river contained the highest distances (534.03 $\mathrm{km}$ ) and carried a higher stream length that defined the area as hydrologically more active. As a result, the velocity of the stream was greater and it consequenced the erosion and sediment transport in the AOI. Figure 6c showed the Spider graph that showed the $1^{\text {st }}$ order stream both instream order and stream length carried the highest value than other stream orders.

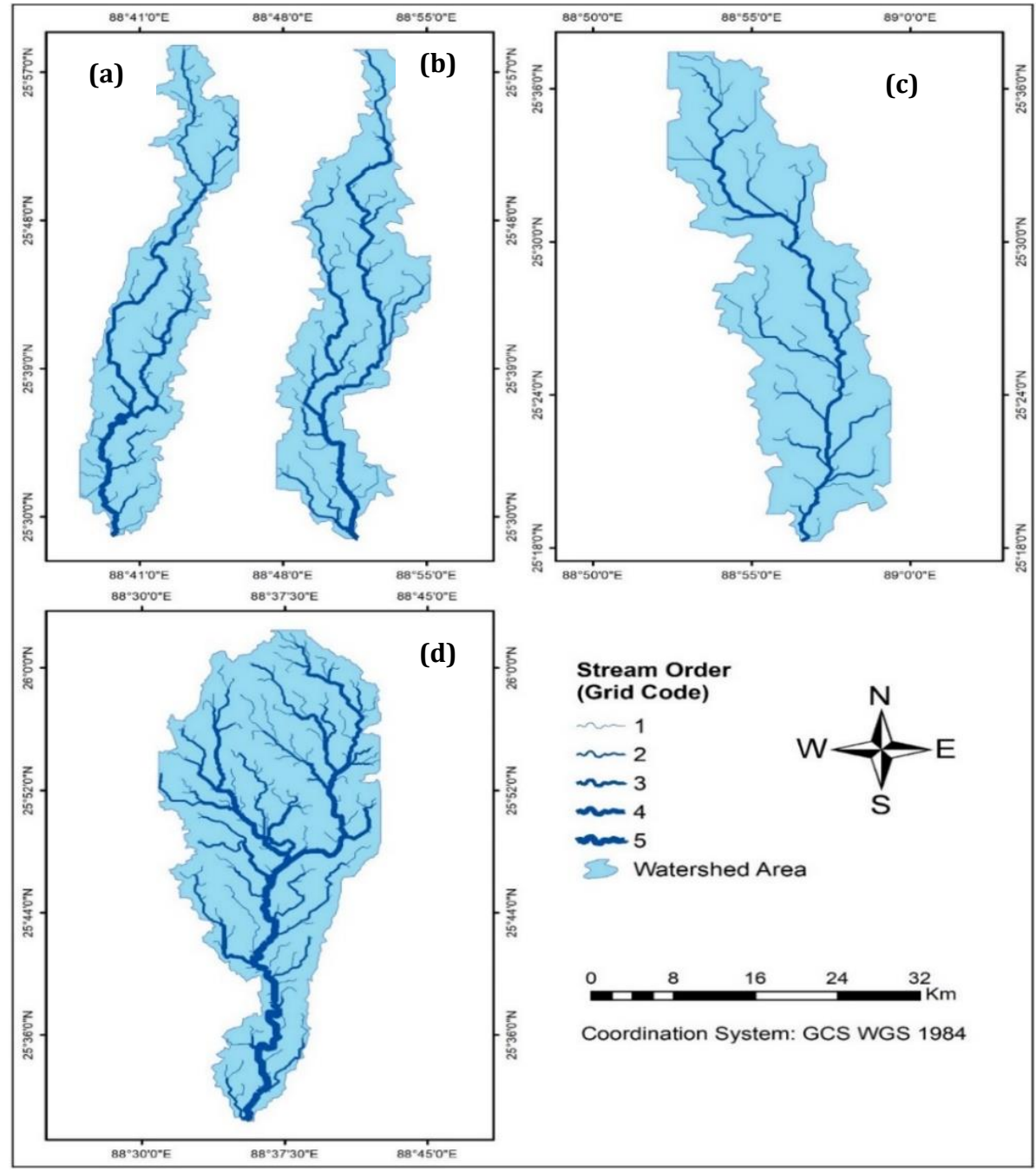

Figure 5: Map of the watershed and stream order of the research area (a) Atrai river part-1, (b) Atrai river part-2, (c) Jamuna river (d) Purnovoba river 


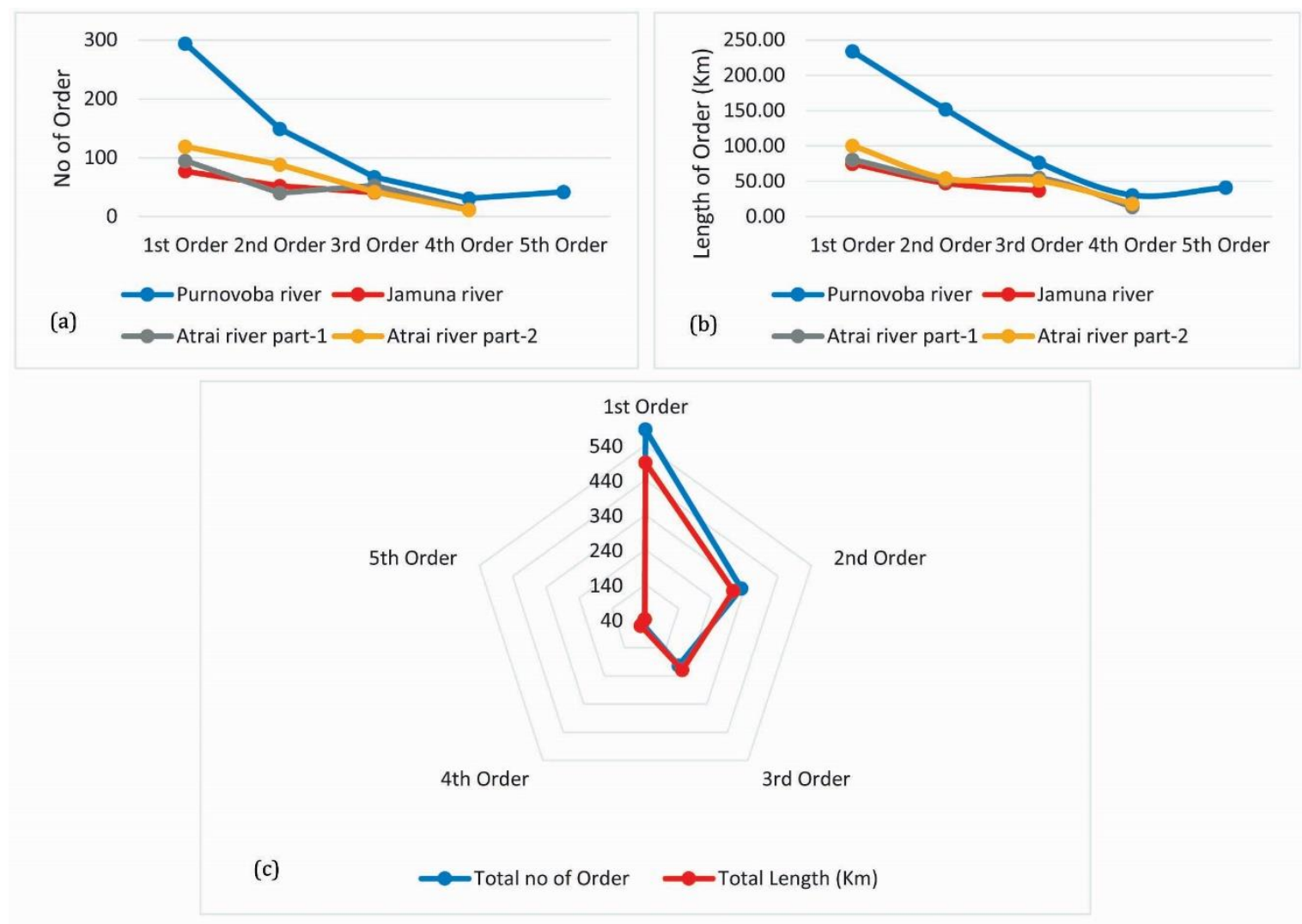

Figure 6: (a) Stream according to no. of order, (b) Stream according to the length of order, and (c) Spider graph of total no of order and total length

\section{Basin Length (Lb)}

Basin length was described as the shape of a basin. The geological structure of a watershed basin was dependent on the length of a basin. In the AOI the Atrai river (part$1 \&$ part-2) contained the highest length of the basin (approximately $63.63 \mathrm{~km}$ ). But in a single watershed area, the Purnovoba river was considered as the highest and more valuable basin length (Table 2). It was computed through equation (1).

\section{E. Bifurcation Ratio (Rb)}

Bifurcation ratio was the foremost parameter linking the hydrological regime in a basin. A high bifurcation ratio suggested the flash flooding during the storm events when the early hydrograph peak was potential. In the study, the maximum bifurcation ratio was 0.9982 and the minimum was 0.2919 (Table 3). Purnovoba river was found with a higher ratio and the Jamuna river was found with a lower ratio. While the mean bifurcation ratio was 0.51969 and at 95\% confidence level it was 0.51779 (Table 4). It was computed through equation (2). The bifurcation ratio was predicted that the Purnovoba river was hydrologically more disturbed than the other three watershed areas. While Atrai river and Jamuna river watershed were delayed to happen any flash flood.

\section{F. Drainage Density (Dd)}

Drainage density was the total length of all the streams in the watershed. It helped to determine the permeability and porosity of the watershed and it conveyed the indicator of landform elements in stream-eroded topography. It was derived using equation (3). Low drainage density led to coarse drainage texture while high drainage density led to fine drainage texture. Drainage density was related to the vegetation, permeability, and development of the basin. Here the mean drainage density was found 0.76681 (Table 4) while the Atrai river part-1 showed higher drainage density, it defined the fine drainage texture and it carried low resistant or permeable subsoil material (Table 3). So, it had low vegetation and less permeable capacity. On the other hand, the Jamuna river had low drainage density and so it had high resistant or permeable subsoil material (Figure 7).

\section{G. Stream Frequency (Fs)}

Stream frequency was defined as computing the unit area that contained the total number of stream segments of all orders. It was extracted by equation (4). Stream frequency was related to permeability, infiltration, and capacity of relief of a watershed. Besides, there is a contradictory relationship between the stream frequency and the number of streams. The present study forecasted the Stream frequency of Purnovoba river, Jamuna river, Atrai river part-1, and Atrai river part-2 watershed were 0.8332, $0.2429,0.2872$, and 0.3716 respectively (Table 3 ), and the mean stream frequency was 0.43378 (Table 4). As the Purnovoba river carried the highest stream frequency It described the watershed area as rocky and with low infiltration capacity (Figure 7d). On the other hand, the Jamuna river carried the lowest stream frequency (Figure 7c). As a result, it was covered with more vegetation with higher permeability and it was less prone to cause flash floods than other watershed areas. 
Table 2

Computation of basic parameters of watershed

\begin{tabular}{lccccc}
\hline \hline Watershed & Area $\left(\mathbf{k m}^{2}\right)$ & $\begin{array}{c}\text { Perimeter } \\
(\mathbf{k m})\end{array}$ & $\begin{array}{c}\text { Total no of } \\
\text { stream order }\end{array}$ & Stream Length (km) & Basin length (km) \\
\hline Purnovoba river & 699.66 & 187199.00 & 583.00 & 534.03 & 54.55 \\
\hline Jamuna river & 217.42 & 114.90 & 170.00 & 159.21 & 28.08 \\
\hline Atrai river part-1 & 244.04 & 146.61 & 201.00 & 200.95 & 33.64 \\
\hline Atrai river part-2 & 298.78 & 166.67 & 260.00 & 223.58 & 146.27 \\
\hline Total & 1459.92 & 187627.20 & 1214.00 & 117.77 & 29.96 \\
\hline \hline
\end{tabular}

Table 3

Computation of linear parameters of watershed

\begin{tabular}{lccccc}
\hline \hline Watershed & Bifurcation ratio & Drainage density & Stream frequency & Texture ratio & Length of overland flow \\
\hline Purnovoba river & 0.9982 & 0.7632 & 0.8332 & 0.0031 & 0.6550 \\
\hline Jamuna river & 0.2919 & 0.7322 & 0.2429 & 1.4794 & 0.6828 \\
\hline Atrai river part-1 & 0.3441 & 0.8234 & 0.2872 & 1.3709 & 0.6072 \\
\hline Atrai river part-2 & 0.4452 & 0.7482 & 0.3716 & 1.5598 & 0.6681 \\
\hline \hline
\end{tabular}

\section{H. Texture Ratio(Tr)}

Texture ratio was influenced by infiltration capacity. There were five different texture classes: very coarse (less than 2 ), coarse (2 to 4 ), moderate (4 to 6 ), fine (6 to 8 ), and very fine (greater than 8) (Altaf et al., 2013). This texture was related to the soil type, infiltration capacity of the watershed basin. It was computed through equation (5). The study ascertained that the minimum texture ratio was 0.0031 for the Purnovoba river, the maximum texture ratio was 1.5598 for the Atrai river part-2 (Table 3), and the average ratio was 1.10335 (Table 4). All the watershed regions apprehended very coarse texture and so the infiltration capacity was decreased.

\section{Length of Overland Flow (Lo)}

Length of overland flow was considered as the traveling distance of a stream over the earth's surface before meeting with the main channel. It was considered the most significant hydrological parameter of the watershed. Besides, the hydrographic development was related to the length of overland flow. The study found that the lengths of overland flow were $0.6072,0.6681,0.6550$, and 0.6828 for Atrai river part-1, Atrai river part-2, Purnovoba river, and Jamuna river respectively (Table 3). It was computed through equation (6). This result forecasted that the slope became gentle for the watershed basin of Atrai river part-1.

\section{J. Form Factor $\left(R_{f}\right)$}

The basins containing high form factors had high peak flows of shorter duration. On the other hand, elongated watershed regions with low form factors had lower peak flows of longer duration. It was computed through equation (7) and the results were displayed in Table 5. Considering the range of form factor 0 to 1 , the maximum and minimum value of form factor defined the possibility of erosion. As the Purnovoba river had the lowest form factor (0.2351), so it had the most possibility for erosion. On the other hand, the Jamuna river watershed contained the highest form factor and it had less possibility for erosion. The mean form factor of the AOI was 0.26151 (Table 7).

\section{K. Shape Factor (Bs)}

If the basin area was circular it had more response to watershed after a storm event. Basin with high shape factor intended to shortest basin lag time and low shape factor intended to longest basin lag time. In the present study, the Purnovoba river watershed was engaged in high shape factor and it was considered as shortest basin lag time (Table 5). Consequently, it provided more responses after a storm event. It was computed through equation (8). 


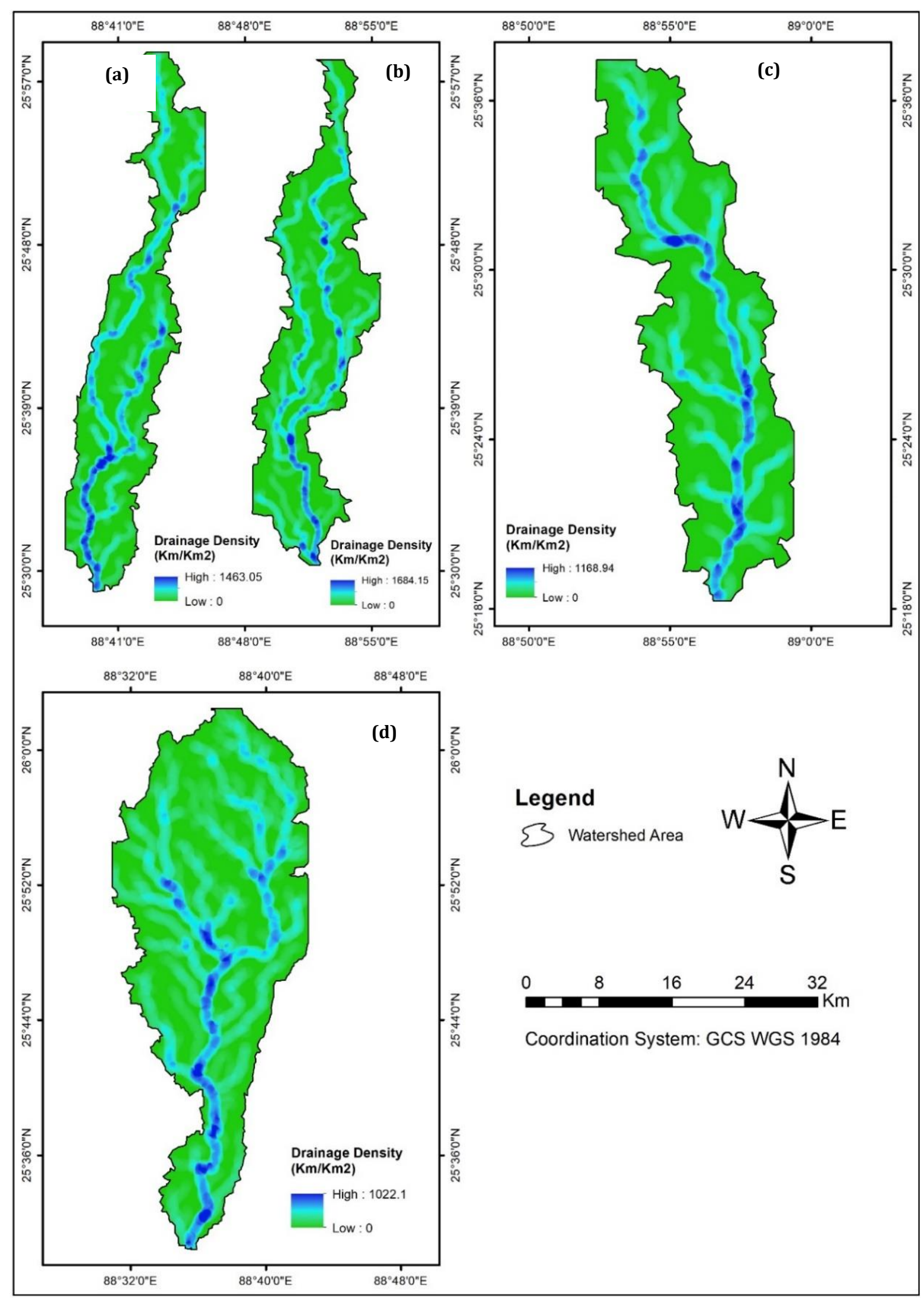

Figure 7: Map of drainage density of the research area (a) Atrai river part-1, (b) Atrai river part-2, (c) Jamuna river (d) Purnovoba river 
Table 4

Statistical parameter analysis of linear aspects

\begin{tabular}{llllll}
\hline \hline Statistical parameter & Rb & Dd & Fs & Tr & Lo \\
\hline Mean & 0.51969 & 0.76681 & 0.43378 & 1.10335 & 0.65333 \\
Standard Error & 0.1627 & 0.0199 & 0.13581 & 0.36878 & 0.01638 \\
\hline Median & 0.39469 & 0.75578 & 0.32944 & 1.42519 & 0.66164 \\
\hline Standard Deviation & 0.3254 & 0.0398 & 0.27161 & 0.73756 & 0.03275 \\
Sample Variance & 0.10589 & 0.00158 & 0.07377 & 0.544 & 0.00107 \\
Kurtosis & 3.20087 & 2.18059 & 3.20087 & 3.7776 & 1.90909 \\
Skewness & 1.7773 & 1.41366 & 1.7773 & -1.9346 & -1.3095 \\
Range & 0.70719 & 0.09115 & 0.59028 & 1.55677 & 0.07559 \\
Minimum & 0.2911 & 0.73226 & 0.24297 & 0.00311 & 0.60723 \\
Maximum & 0.99829 & 0.82341 & 0.83326 & 1.55989 & 0.68282 \\
Sum & 2.07877 & 3.06722 & 1.73512 & 4.41338 & 2.61332 \\
Count & 4 & 4 & 4 & 4 & 4 \\
Confidence Level (95.0\%) & 0.51779 & 0.06334 & 0.43219 & 1.17363 & 0.05212 \\
\hline \hline
\end{tabular}

Table 5

Computation of shape parameters of watershed

\begin{tabular}{lllll}
\hline \hline Watershed & Form factor & Shape factor & Elongation ratio & Compact co-efficient \\
\hline Purnovoba river & 0.2351 & 4.2531 & 4.0397 & 1996.9 \\
\hline Jamuna river & 0.2756 & 3.6281 & 3.1384 & 2.1988 \\
\hline Atrai river part-1 & 0.2713 & 3.6855 & 3.2177 & 2.6481 \\
Atrai river part-2 & 0.2639 & 3.7883 & 3.3615 & 2.7208 \\
\hline \hline
\end{tabular}

\section{Elongation Ratio (Re)}

The elongation ratio was related to the shape of the watershed basin and a standard was developed to demarcate the shape of an analyzed basin (Table 6). It was computed through equation (9). The elongation ratio of the experimented watershed basin was shown in (Table 5) and the results narrated that the basins were more elongated (Table 6). The mean elongation ratio was 3.43937 (Table 7).

\section{Compactness Co-efficient (Cc)}

The compactness coefficient explained the relationship between the area of a basin and the circular shape of that basin. Table 5 showed the coefficient factor where all the basins were above 1 that expounded the basin shapes were more deviation from the circular shape. Table 6 showed the elongation ratio range with its basin shape. Here the mean value of the compactness coefficient was 501.3 which examined that the shape of the interested watershed basin largely deviated from the circular shape (Table 7). It was computed through equation (10).

Table 6

Basin shape by elongation ratio

\begin{tabular}{ll}
\hline \hline Elongation Ratio & Basin Shape \\
\hline$>0.5$ & More Elongated \\
\hline $0.5-0.7$ & Elongated \\
\hline $0.7-0.8$ & Less Elongated \\
\hline $0.8-0.9$ & Oval \\
\hline $0.9-1.0$ & Circular \\
\hline
\end{tabular}


Table 7

Statistical parameters analysis of shape aspects

\begin{tabular}{|c|c|c|c|c|}
\hline Statistical parameters & $\mathbf{R f}$ & Bs & $\mathbf{R e}$ & Cc \\
\hline Mean & 0.26151 & 3.8388 & 3.43937 & 501.126 \\
\hline Standard Error & 0.00912 & 0.14204 & 0.20538 & 498.603 \\
\hline Median & 0.26765 & 3.73697 & 3.28964 & 2.68452 \\
\hline Standard Deviation & 0.01824 & 0.28408 & 0.41076 & 997.206 \\
\hline Sample Variance & 0.00033 & 0.0807 & 0.16873 & 994420 \\
\hline Kurtosis & 2.58127 & 2.8806 & 2.95976 & 4 \\
\hline Skewness & -1.6043 & 1.68828 & 1.71033 & 2 \\
\hline Range & 0.04051 & 0.62505 & 0.90129 & 1994.74 \\
\hline Minimum & 0.23512 & 3.6281 & 3.13846 & 2.19886 \\
\hline Maximum & 0.27563 & 4.25315 & 4.03974 & 1996.94 \\
\hline Sum & 1.04604 & 15.3552 & 13.7575 & 2004.5 \\
\hline Count & 4 & 4 & 4 & 4 \\
\hline Confidence Level (95.0\%) & 0.02903 & 0.45204 & 0.65361 & 1586.78 \\
\hline
\end{tabular}

\section{CONCLUSIONS}

The Barind region, Dinajpur district was selected for its special geographical character like its undulating topography having impenetrable and low productive soils. About 14 sub-parameters were analyzed and these subparameters were categorized into three parameters like basic, linear, and shape parameter. Under the basic parameter, the Purnovoba river had the highest area and maximum perimeter. Besides, the Purnovoba river was found a higher discharged rate and greater velocity of the stream as it contained the higher stream order $\left(5^{\text {th }}\right.$ order $)$. On the other hand, the Jamuna river had only $3^{\text {rd }}$ order and stream length was only $159.21 \mathrm{~km}$. The aftermath ascertained that the Jamuna river was considered as a lower discharged rate and fewer velocity of the stream. As the basin length described the geological structure of any watershed region Atrai river (part-1 \& part-2) contained the highest length of basin. The bifurcation ratio of the Purnovoba river indicated the lack of structural control over the formation of drainage patterns and it was hydrologically more disturbed than other watersheds. In the study, the Atrai river part-1 was found a higher drainage density. The higher drainage density described the low vegetation and less permeable capacity. Jamuna river was considered as a lower drainage density that had high permeable subsoil material. Permeability, infiltration, and capacity of relief of any watershed depended on stream frequency. As the Purnovoba river had a higher stream frequency, it was rocky and low infiltration capacity. On the other hand, the Jamuna river was covered with more vegetation with higher permeability and less prone to cause flash floods. As the texture ratio was related to soil type or texture class and infiltration capacity of the watershed basin, the Purnovoba river resulted in decreasing infiltration capacity which decreased the availability of groundwater. In the study area, the length of overland flow resulted that the slope became gentle to Atrai river part-1. Under the shape parameter, the Jamuna river had a high form factor that defined the high peak flows with shorter duration and the Purnovoba river had a low form factor that defined the lower peak flows with longer duration. Measuring the shape factor, Purnovoba river contained a high shape factor with the shortest basin lag time and Atrai river part-2 contained a low shape factor with the longest basin lag time. As the value of elongation ratio was $>1$, all the watershed basins were considered as the deviation of the circular form. These findings will help for further modeling of an integrated watershed for sustainable hydrological and hydrograph models in the Barind region of Bangladesh. Besides, it will help the policymakers, planners, geographers, environmentalists, and many more who use GIS and RS techniques for solving hydrologyrelated problems such as irrigation, harvesting of surface water, cause of river erosion, surface stormwater runoff process, and water resource management.

\section{ACKNOWLEDGEMENTS}

The authors would like to thank the Survey of Bangladesh (SoB) and Bangladesh Meteorological Department for assisting this research by sharing the data-sets, . The authors are also thankful to the Dept. of URP at KUET, Khulna, 
Dept. of URP at RUET, Rajshahi, and IBBBS at BSMRMU, Dhaka for providing the the software and lab assistances.

\section{REFERENCES}

Ahmed, S., Chandrashekarappa, K., Raj, S., Nischitha, V., \& Kavitha, G. (2010). Evaluation of morphometric parameters derived from ASTER and SRTM DEM-a study on Bandihole sub-watershed basin in Karnataka. Indian society of remote sensing, 38(2), 227-238.

Ahn, S.-R., \& Kim, S.-J. (2019). Assessment of watershed health, vulnerability and resilience for determining protection and restoration Priorities. Environmental Modelling \& Software, 122, 103926.

Al-Assadi, K. H. F. (2020). Analyzing the morphometric characteristics of Wadi Mezal basin using geographical information systems. Groundwater for Sustainable Development, 100436.

Alam, A., Ahmed, B., \& Sammonds, P. (2020). Flash flood susceptibility assessment using the parameters of drainage basin morphometry in SE Bangladesh. Quaternary International.

Alnahit, A. O., Mishra, A. K., \& Khan, A. A. (2020). Quantifying climate, streamflow, and watershed control on water quality across Southeastern US watersheds. Science of The Total Environment, 139945.

Altaf, F., Meraj, G., \& Romshoo, S. A. (2013). Morphometric analysis to infer hydrological behaviour of Lidder watershed, Western Himalaya, India. Geography Journal, 2013.

Ameri, A. A., Pourghasemi, H. R., \& Cerda, A. (2018). Erodibility prioritization of sub-watersheds using morphometric parameters analysis and its mapping: A comparison among TOPSIS, VIKOR, SAW, and CF multi-criteria decision making models. Science of the Total Environment, 613, 1385-1400.

Amiri, M., Pourghasemi, H. R., Arabameri, A., Vazirzadeh, A., Yousefi, H., \& Kafaei, S. (2019). Prioritization of flood inundation of Maharloo Watershed in iran using morphometric parameters analysis and TOPSIS MCDM model. In Spatial modeling in GIS and R for earth and environmental sciences (pp. 371-390): Elsevier.

Balasubramanian, A., Duraisamy, K., Thirumalaisamy, S., Krishnaraj, S., \& Yatheendradasan, R. K. (2017). Prioritization of subwatersheds based on quantitative morphometric analysis in lower Bhavani basin, Tamil Nadu, India using DEM and GIS techniques. Arabian Journal of Geosciences, 10(24), 552.

Banerjee, A., Singh, P., \& Pratap, K. (2017). Morphometric evaluation of Swarnrekha watershed, Madhya Pradesh, India: an integrated GIS-based approach. Applied Water Science, 7(4), 1807-1815.

Chandniha, S. K., \& Kansal, M. L. (2017). Prioritization of sub-watersheds based on morphometric analysis using geospatial technique in Piperiya watershed, India. Applied Water Science, 7(1), 329-338.

Charizopoulos, N., Mourtzios, P., Psilovikos, T., Psilovikos, A., \& Karamoutsou, L. (2019). Morphometric analysis of the drainage network of Samos Island (northern Aegean Sea): Insights into tectonic control and flood hazards. Comptes Rendus Geoscience, 351(5), 375-383.
Chatterjee, S., Krishna, A., \& Sharma, A. (2014). Geospatial assessment of soil erosion vulnerability at watershed level in some sections of the Upper Subarnarekha river basin, Jharkhand, India. Environmental earth sciences, 71(1), 357-374.

Choudhari, P., Nigam, G. K., Singh, S. K., \& Thakur, S. (2018). Morphometric based prioritization of watershed for groundwater potential of Mula river basin, Maharashtra, India. Geology, Ecology, and Landscapes, 2(4), 256-267.

Dragičević, N., Karleuša, B., \& Ožanić, N. (2018). Improvement of Drainage Density Parameter Estimation within Erosion Potential Method. Paper presented at the Multidisciplinary Digital Publishing Institute Proceedings.

Du, H., Dou, S., Deng, X., Xue, X., \& Wang, T. (2016). Assessment of wind and water erosion risk in the watershed of the Ningxia-Inner Mongolia Reach of the Yellow River, China. Ecological Indicators, 67, 117131.

Elsadek, W. M., Ibrahim, M. G., \& Mahmod, W. E. (2019). Runoff hazard analysis of Wadi Qena Watershed, Egypt based on GIS and remote sensing approach. Alexandria Engineering Journal, 58(1), 377-385.

Ervinia, A., Huang, J., Huang, Y., \& Lin, J. (2019). Coupled effects of climate variability and land use pattern on surface water quality: An elasticity perspective and watershed health indicators. Science of The Total Environment, 693, 133592.

Fu, X., Hopton, M. E., Wang, X., Goddard, H., \& Liu, H. (2019). A runoff trading system to meet watershed-level stormwater reduction goals with parcel-level green infrastructure installation. Science of The Total Environment, 689, 1149-1159.

Gajbhiye, S., Mishra, S., \& Pandey, A. (2014). Prioritizing erosion-prone area through morphometric analysis: an RS and GIS perspective. Applied Water Science, 4(1), 51-61.

Ghorbani Nejad, S., Falah, F., Daneshfar, M., Haghizadeh, A., \& Rahmati, O. (2017). Delineation of groundwater potential zones using remote sensing and GIS-based data-driven models. Geocarto international, 32(2), 167187.

Gong, J., \& Xie, J. (2009). Extraction of drainage networks from large terrain datasets using high throughput computing. Computers \& Geosciences, 35(2), 337-346.

Harmel, R., Cooper, R., Slade, R., Haney, R., \& Arnold, J. (2006). Cumulative uncertainty in measured streamflow and water quality data for small watersheds. Transactions of the ASABE, 49(3), 689-701.

Harsha, J., Ravikumar, A., \& Shivakumar, B. (2020). Evaluation of morphometric parameters and hypsometric curve of Arkavathy river basin using RS and GIS techniques. Applied Water Science, 10(3), 115.

Horton, R. E. (1945). Erosional development of streams and their drainage basins; hydrophysical approach to quantitative morphology. Geological society of America bulletin, 56(3), 275-370. 
Javed, A., Khanday, M. Y., \& Rais, S. (2011). Watershed prioritization using morphometric and land use/land cover parameters: a remote sensing and GIS based approach. Geological Society of India, 78(1), 63.

Liu, B.-W., Wang, M.-H., Chen, T.-L., Tseng, P.-C., Sun, Y., Chiang, A., \& Chiang, P.-C. (2020). Establishment and Implementation of Green Infrastructure Practice for Healthy Watershed Management: Challenges and Perspectives. Water-Energy Nexus.

Liu, K., Song, C., Ke, L., Jiang, L., \& Ma, R. (2020). Automatic watershed delineation in the Tibetan endorheic basin: A lake-oriented approach based on digital elevation models. Geomorphology, 107127.

Metz, M., Mitasova, H., \& Harmon, R. (2011). Efficient extraction of drainage networks from massive, radarbased elevation models with least cost path search. Retrieved from

Mokarram, M., \& Hojati, M. (2017). Morphometric analysis of stream as one of resources for agricultural lands irrigation using high spatial resolution of digital elevation model (DEM). Computers and Electronics in Agriculture, 142, 190-200.

Okumura, M., \& Araujo, A. G. (2014). Long-term cultural stability in hunter-gatherers: a case study using traditional and geometric morphometric analysis of lithic stemmed bifacial points from Southern Brazil. Archaeological Science, 45, 59-71.

Panhalkar, S., Mali, S., \& Pawar, C. (2012). Morphometric analysis and watershed development prioritization of Hiranyakeshi Basin in Maharashtra, India. International journal of environmental sciences, 3(1), 525-534.

Patel, D. P., Dholakia, M. B., Naresh, N., \& Srivastava, P. K. (2012). Water harvesting structure positioning by using geo-visualization concept and prioritization of mini-watersheds through morphometric analysis in the Lower Tapi Basin. Indian society of remote sensing, 40(2), 299-312.

Pondari, S., Dandabathula, G., Bera, A., Nagamani, P., \& Amminedu, E. (2020). Characterization of drainage network of Brahmaputra river basin in Indian subcontinent using geospatial technologies. Science, Technology and Environment Informatics, 8(01), 583594.

Poongodi, R., \& Venkateswaran, S. (2018). Prioritization of the micro-watersheds through morphometric analysis in the Vasishta Sub Basin of the Vellar River, Tamil Nadu using ASTER Digital Elevation Model (DEM) data. Data in brief, 20, 1353-1359.

Prasannakumar, V., Vijith, H., \& Geetha, N. (2013). Terrain evaluation through the assessment of geomorphometric parameters using DEM and GIS: case study of two major sub-watersheds in Attapady, South India. Arabian Journal of Geosciences, 6(4), 1141-1151.

Rashid, M. B., Islam, M. B., \& Sultan-Ul-Islam, M. (2013). Causes of acute water scarcity in the Barind Tract, Bangladesh. Economic and Environment Geology, 4(1), 5-14.

Ratnam, K. N., Srivastava, Y., Rao, V. V., Amminedu, E., \& Murthy, K. (2005). Check dam positioning by prioritization of micro-watersheds using SYI model and morphometric analysis-remote sensing and GIS perspective. Indian society of remote sensing, 33(1), 25.

Rong, Q., Cai, Y., Su, M., Yue, W., Yang, Z., \& Dang, Z. (2019). A simulation-based bi-level multi-objective programming model for watershed water quality management under interval and stochastic uncertainties. Environmental Management, 245, 418-431.

Saha, A., Joseph, J., \& Ghosh, S. (2020). Climate controls on the terrestrial water balance: Influence of aridity on the basin characteristics parameter in the Budyko framework. Science of The Total Environment, 139863.

Schumm, S. A. (1956). Evolution of drainage systems and slopes in badlands at Perth Amboy, New Jersey. Geological society of America bulletin, 67(5), 597-646.

Senter, A. E., Pasternack, G. B., Piegay, H., Vaughan, M. C., \& Lehyan, J. S. (2017). Wood export varies among decadal, annual, seasonal, and daily scale hydrologic regimes in a large, Mediterranean climate, mountain river watershed. Geomorphology, 276, 164-179.

Soni, S. (2017). Assessment of morphometric characteristics of Chakrar watershed in Madhya Pradesh India using geospatial technique. Applied Water Science, 7(5), 2089-2102.

Sreedevi, P., Owais, S., Khan, H., \& Ahmed, S. (2009). Morphometric analysis of a watershed of South India using SRTM data and GIS. Geological Society of India, 73(4), 543-552.

Strahler, A. N. (1964). Handbook of applied hydrology. Quantitative geomorphology of drainage basins and channel networks. New York, NY: Mc-Graw Hill Book Company, 39-76.

Sujatha, E. R., Selvakumar, R., \& Rajasimman, B. (2014). Watershed prioritization of Palar sub-watershed based on the morphometric and land use analysis. Mountain Science, 11(4), 906-916.

Suresh, M., Sudhakar, S., Tiwari, K., \& Chowdary, V. (2004). Prioritization of watersheds using morphometric parameters and assessment of surface water potential using remote sensing. Indian society of remote sensing, 32(3), 249-259.

Tykocki, T., du Plessis, J., \& Wynne-Jones, G. (2018). Analysis of morphometric parameters in cervical canal stenosis on neutral and dynamic magnetic resonance imaging. World neurosurgery, 114, e317-e322.

Wada, C. A., Pongkijvorasin, S., \& Burnett, K. M. (2020). Mountain-to-sea ecological-resource management: Forested watersheds, coastal aquifers, and groundwater dependent ecosystems. Resource and Energy Economics, 59, 101146.

Withanage, N., Dayawansa, N., \& De Silva, R. (2014). Morphometric analysis of the Gal Oya river basin using spatial data derived from GIS. Tropical Agricultural Research, 26(1), 175-188. 